Transport and Communications Science Journal, Vol. 71, Issue 4 (05/2020), 380-387

Transport and Communications Science Journal

\title{
AN EXPERIMENTAL INVESTIGATION OF THE BOND BEHAVIOR BETWEEN THE REINFORCEMENT AND LIGHTWEIGHT AGGREGATE CONCRETE
}

\author{
Dang Thuy Chi ${ }^{1}$, Le Minh Cuong ${ }^{1}$ \\ ${ }^{1}$ University of Transport and Communications, No 3 Cau Giay Street, Hanoi, Vietnam.
}

\section{ARTICLE INFO}

TYPE: Research Article

Received: 30/12/2019

Revised: 22/04/2020

Accepted: 26/04/2020

Published online: 28/5/2020

https://doi.org/10.25073/tcsj.71.4.7

* Corresponding author

Email: thuychi.dang@utc.edu.vn

Abstract. Bond behavior between the reinforcement steel bars and surrounding concrete is considered as an important characteristic for reinforced concrete structures, including lightweight aggregate concrete ones. This paper presents an experimental investigation on the bond behavior of $14 \mathrm{~mm}$ diameter steel bars embedded in lightweight aggregate concrete. The bond slip relationship between rebar and lightweight aggregate concrete shows a conventional behavior, similar to traditional reinforced concrete. The development length of 14 diameter steel embedded in lightweight aggregate concrete is smaller than the requirement in ACI 31811.

Keywords: lightweight aggregate concrete, bond behavior, reinforcement steel, development length, experiment

C 2020 University of Transport and Communications

\section{INTRODUCTION}

Lightweight aggregate concrete (LWAC) has been used successfully for structural purposes for many years. Regarding to reinforced structural applications of lightweight aggregate concrete, the interface between concrete and steel bars that bond strength occurs has the potential to be the weakest part of the structure. Due to the huge impact of the bond on the whole structure, it is important to have a clear understanding of its behavior. 
Over the years, researchers have attempted to carry out comprehension of the bond strength of LWAC. Chen et al., 2004 [1] carried out experimental investigations on the LWAC with expanded clay aggregates. He found that in concrete with compressive strength below $40 \mathrm{MPa}$, the bond strength of normal weight concrete was higher compared to expanded clay LWAC but the opposite was noticed when the compressive strength exceeded $40 \mathrm{MPa}$. This was attributed to the aggregate strength which governed the bond strength at low compressive strength level while the mortar strength influenced the bond strength of concrete with higher compressive strength.

In case of LWAC made with expanded shale aggregates, Yang et al., 2012 [2] and Zhang et al., 2014 [3] reported that the bond strength of LWAC made of shale ceramsite aggregate is comparable to that of normal weight concrete. In the investigation utilizing slag as lightweight aggregate, Mayfield and Louati, 1990 [4] reported similar bond strengths of LWAC made of pelletized blast furnace slag aggregate and normal weight concrete of equivalent compressive strength. Trade et al, 2018 [5] showed that Eurocode rule for additional concrete cover in case of lightweight concrete (EN 1992-1-1 Sect. 11.4.2) may be omitted for structural lightweight concrete with densities greater than $1600 \mathrm{~kg} / \mathrm{m}^{3}$.

In fact, the determining of the bond behavior between lightweight aggregate concrete and steel bars helps to calculate the development length of reinforcement as well as the distance and width of cracks in the reinforced lightweight aggregate concrete structure.

Most of design standards, especially Vietnamese ones, regulate only the development length of reinforcement for traditional concrete. The paper introduces the empirical research according to EN10080:2005 [6] to determine the adhesive behavior between lightweight reinforced concrete and bars of diameter $14 \mathrm{~mm}(\phi 14)$.

\section{EXPERIMENTAL PROGRAM AND RESULTS}

\section{II.1. Material properties}

Hand mixed concrete was used to cast the specimens. The mix design of the lightweight aggregate concrete is presented in Table 1.

Table 1. Mix proportion of structure LWAC.

\begin{tabular}{|l|c|}
\hline Composition of LWAC & kg \\
\hline Cement & 643 \\
\hline Water & 170 \\
\hline Da Phuc Sand & 937 \\
\hline Lightweight aggregate & 194 \\
\hline Silica fume & 64.3 \\
\hline Superplasticizer & 9.6 \\
\hline
\end{tabular}

The compressive strength was carried out on $100 \times 300 \mathrm{~mm}$ cylinders. The slump was tested immediately after mixing and the density of the LWAC was measured at 28-day age. The results of the properties of the LWAC are shown in Table 2. 
Transport and Communications Science Journal, Vol. 71, Issue 4 (05/2020), 380-387

Reinforcement used in this study is CB300-V ribbed bars of $14 \mathrm{~mm}$ diameter which have the properties suitable to TCVN 1651-2: 2008 [7]. Yield strength of rebar $\mathrm{f}_{\mathrm{y}}$ is $300 \mathrm{MPa}$.

Table 2. Properties of the LWAC.

\begin{tabular}{|l|c|c|}
\hline \multicolumn{1}{|c|}{ Index } & Unit & Value \\
\hline Density & $\mathrm{Kg} / \mathrm{m}^{3}$ & 1830 \\
\hline Slump & $\mathrm{cm}$ & 20 \\
\hline $\begin{array}{l}\text { 28-day average } \\
\text { compressive strength }\end{array}$ & $\mathrm{MPa}$ & 35 \\
\hline
\end{tabular}

\section{II.2. Experimental program}

The pull-out tests were conducted following a procedure similar to EN 10080:2005 [6] and the testing principle is shown in Figure 1. The method was chosen because it has been standardized and the experimental model can be performed relatively easily, suitable for available equipment.
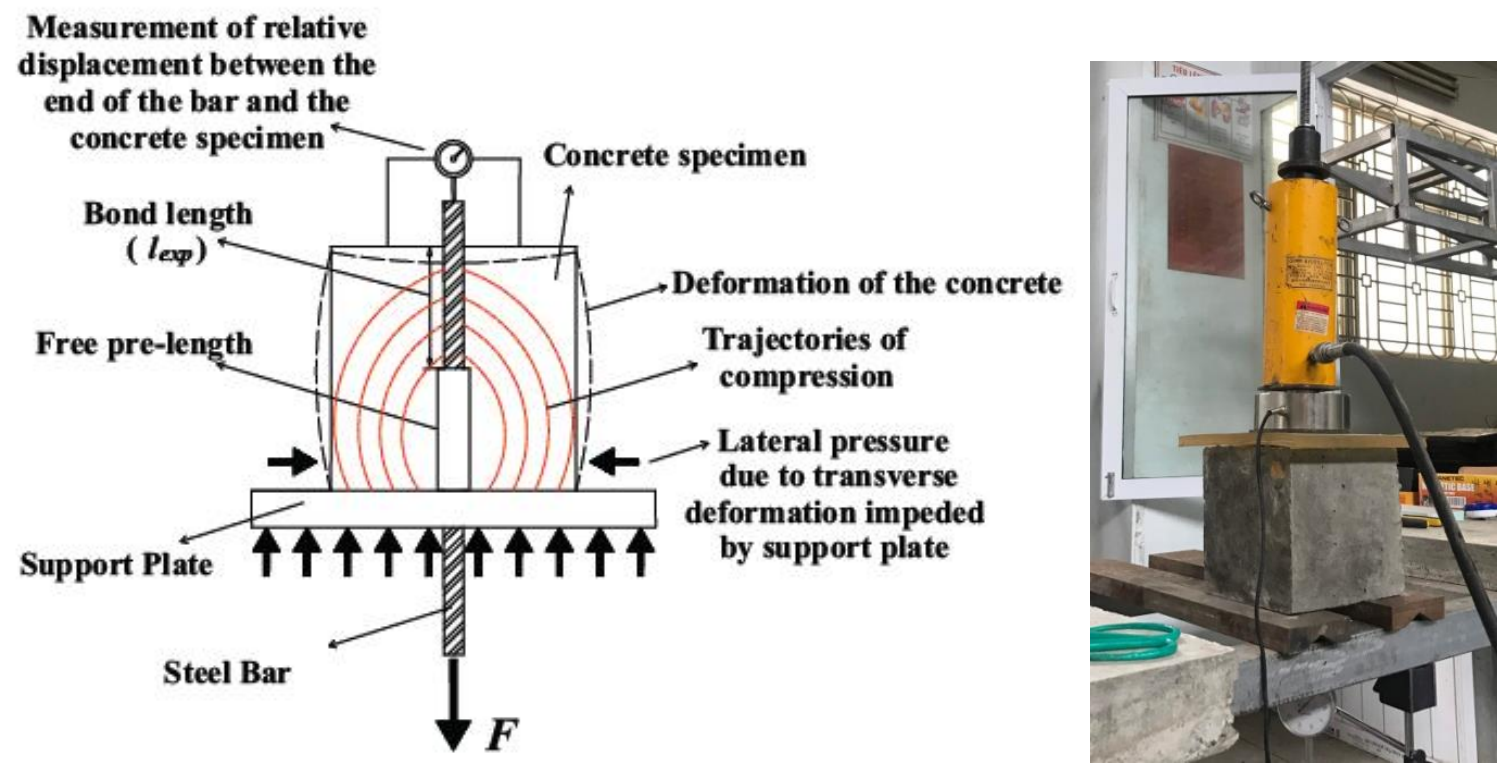

Figure 1. The pull-out testing principle.

The principle of the test is to load a bar that is incorporated in a concrete cube, along a defined length, by a tensile force. The other end of the bar remains without stress. The relation between the tensile force and the slip (i.e. the relative displacement between steel and concrete) is measured up to failure. The force is increased up to failure of the bond or until the reinforcement itself fails.

The test specimen is a cube of concrete where the bar is located in the center of the cube. The effective bond length of the bar is $5 \mathrm{~d}$ and corresponds only to a part of the specimen. In the other part of the bar bond is prevented. The bar to be tested extends beyond the two sides of the specimen; the tension is applied to the longer end, and the device for measuring the slip is set on the shorter end. 
In this study, the specimens of LWAC for the pull-out test were the cubes of 20x20x20 $\mathrm{cm}$. The $14 \mathrm{~mm}$ diameter reinforcements (d) were used and the length of embedment in concrete samples is $5 \mathrm{~d}$. The number of samples tested was six samples. The specimens were cured in natural conditions for 28 days.

The specimens were tested under the static loading. The loading device is a 20 -ton RCH20-155 hydraulic cylinder (China). The traction is measured by a 30-ton CFBLY loadcell (China). During the experiment, the measurement data was recorded by using a DRA30A meter (TML - Japan) connected to the computer with a specialized software. The linear variable different transducer (LVDT) was installed, respectively, on the free end to measure the rebar's displacements; test must be ceased while the displacement of the free end exceeded $2 \mathrm{~mm}$. The experiments were performed at the Materials and Structural Laboratory, University of Transport and Communication.

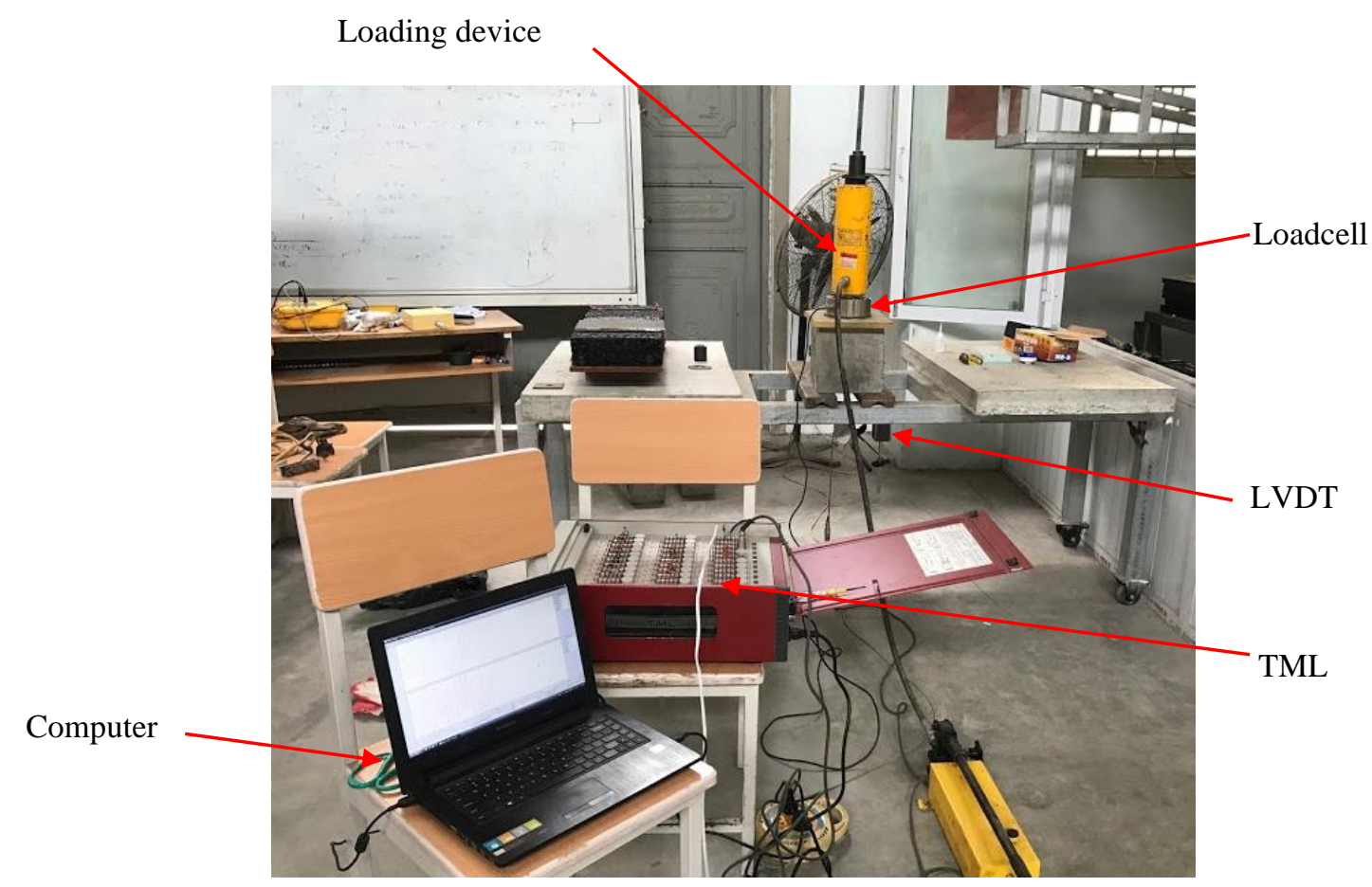

Figure 2. The pull - out testing set-up.

\section{TEST RESULTS}

Experimental results of the pull-out tests are presented in Figure 3. Six load versus slip curves respectively six sample experiments were observed. The bond behavior between LWAC and reinforcement consists of 4 stages similar to the one between steel bars and ordinary concrete [8], [9]. In the first stage, uncracked concrete corresponds to an almost vertical increasing of the tensile load. At this stage, the bond strength is smaller than tensile strength of concrete. In the second stage, cracks appear in the concrete surrounding bars (horizontal cracks, round). At this stage, the stiff decreases and the large strain cause the big change of the curve slope. In the third stage, bond stress continues to increase. At this stage, cracks appear along the reinforcement bars and develop to the outside of the structure. When the peak stress is reached, the slip increases but the load decreases. Finally, the friction through wedging of the bars deformations on the surrounding concrete becomes the predominant bond mechanism. The residual bond stress which value is a constant sustains till the bar pulled out from the LWAC. 
Transport and Communications Science Journal, Vol. 71, Issue 4 (05/2020), 380-387

The curves are quite similar. The values of the load (stress) measured at the same displacement are so close, so the experiments results were reliable and accurate.

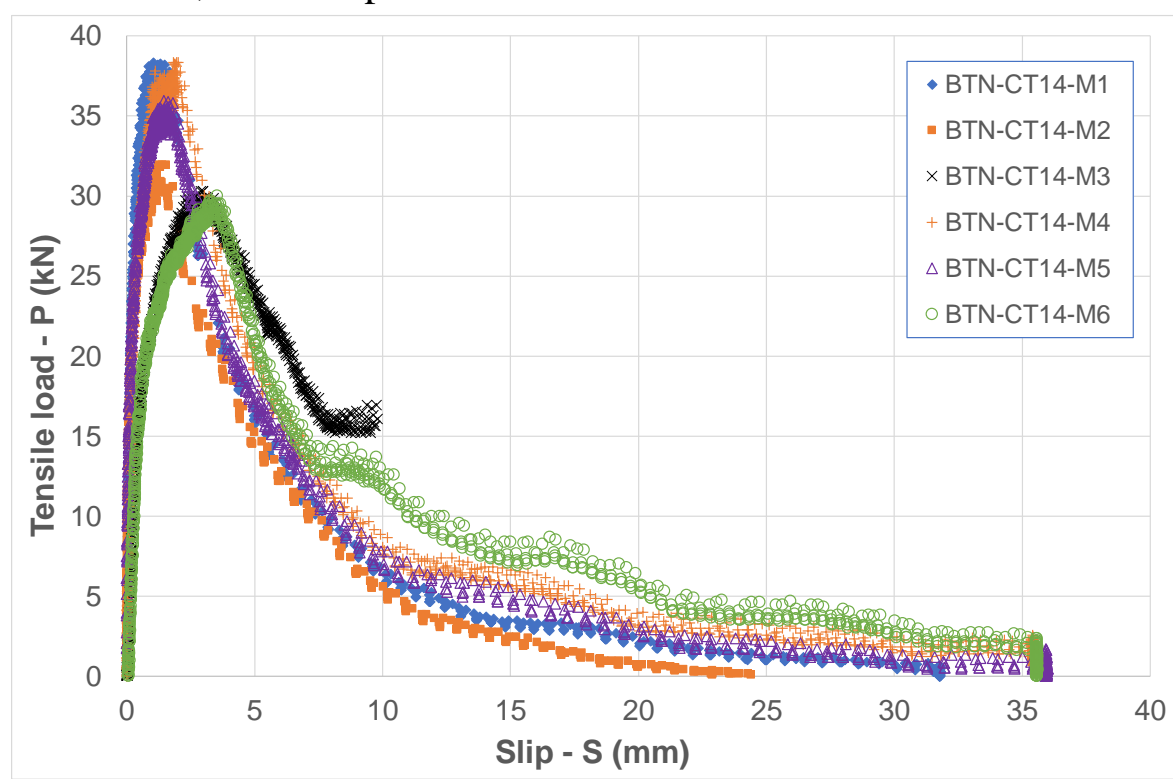

Figure 3. The load - slip curves of the test specimens.

The value of average nominal bond stress can be calculated as the normal force divided by the surface area of the rebar embedded in the concrete. For circular cross section reinforcing bar of which the diameter is, the average bond strength can be calculated by the following formula:

$$
f_{d b}=P_{\max } /\left(\pi \cdot d_{b} \cdot L_{d b}\right),(M P a)
$$

Where $L_{d b}$ is the length of embedment and $d_{b}$ is the nominal diameter of the reinforcement. The maximum average bond stress of each specimen can be calculated from eq. (1) while the maximum tensile load occurs.

The figure 4 presents the bond stress versus slip between rebars and LWAC curves.

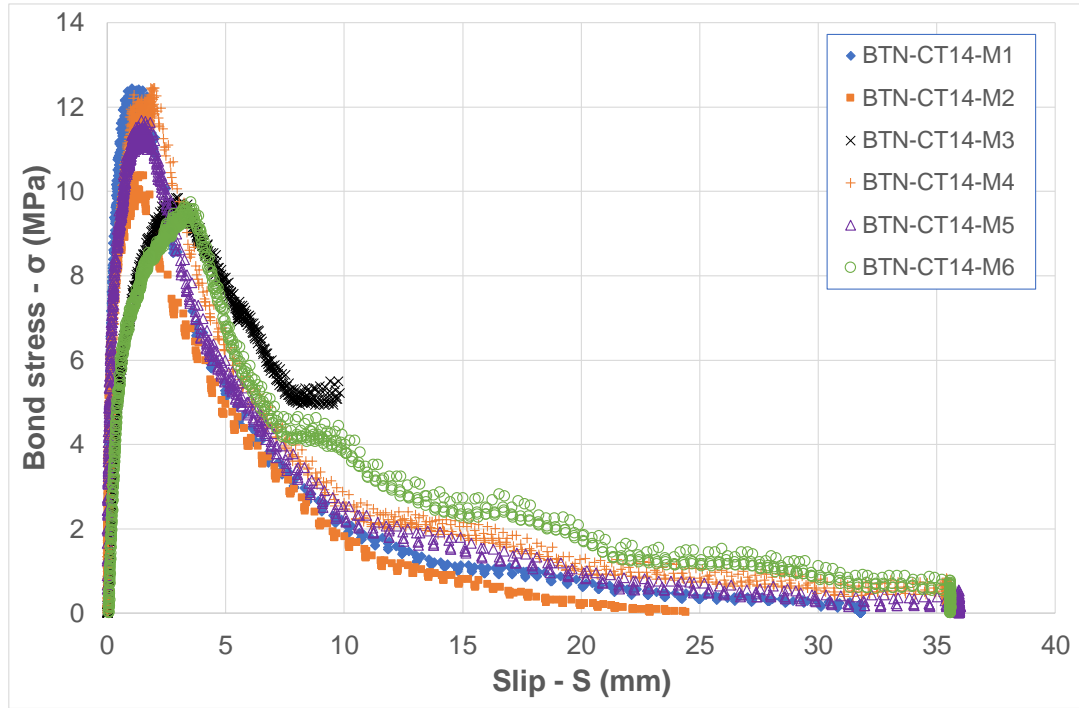

Figure 4 . The bond stress - slip curves of the test specimens. 
Slipping at the free end of the bar began while the load approached the maximum and was increasing quickly; then the bar was pulled out. So the specimen was damaged for the tensile reinforcement was pulled out as shown in Figure 5.

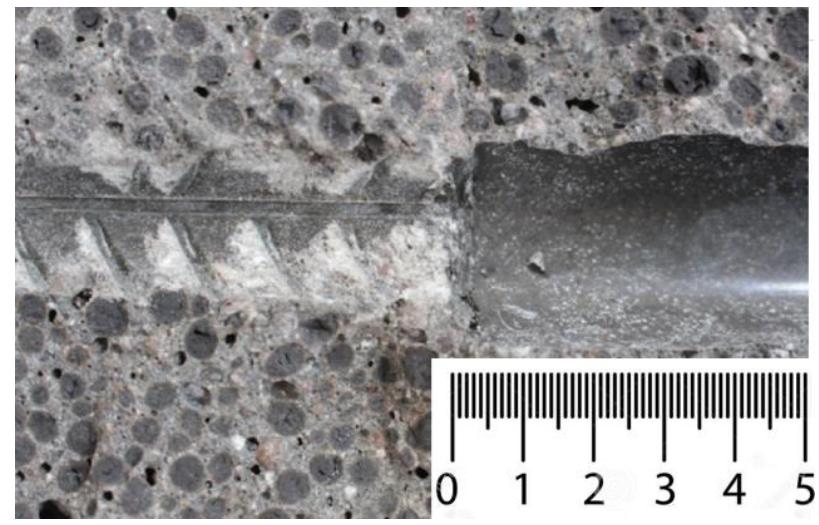

Figure 5. Pull-out failure of specimens.

The nominal stress between rebars $\phi 14$ and LWAC $\left(\mathrm{f}^{\prime}{ }_{\mathrm{c}}=35 \mathrm{MPa}\right)$ of six experimental samples varied from 9.75 to $12.45 \mathrm{MPa}$. This result is quite similar to that of Holschemacher et al. [10]. The tests of pulling the rebars $\phi 16$ out of LWAC samples $\left(f^{\prime}{ }_{\mathrm{cr}}=37.98 \mathrm{MPa}\right)$ in the research of Holschemacher et al. [10] showed the average bond stress from 10.22 to 13.07MPa. As a reason for the number of test samples is not enough to evaluate the probability, therefore the standard deviation $S$ and the coefficient of variation $C_{V}$ of the experimental results were calculated for provide a preliminary assessment of the test results (Table 3).

Table 3. The average bond stress between rebars $\phi 14$ and LWAC.

\begin{tabular}{|c|c|c|c|c|c|}
\hline Samples & $\begin{array}{c}\mathrm{P}_{\max } \\
(\mathrm{kN})\end{array}$ & $\begin{array}{c}\mathrm{f}_{\mathrm{db}} \\
(\mathrm{MPa})\end{array}$ & $\begin{array}{c}\mathrm{f}_{\mathrm{db} 0,25 \mathrm{tb}} \\
(\mathrm{MPa})\end{array}$ & $\begin{array}{c}\mathrm{S} \\
(\mathrm{MPa})\end{array}$ & $\mathrm{Cv}$ \\
\cline { 1 - 3 } 1 & 37.2 & 12.1 & & & \\
\cline { 1 - 3 } 2 & 31.9 & 11.4 & & & \\
\cline { 1 - 3 } 3 & 30.3 & 9.8 & \multirow{2}{*}{11.03} & \multirow{2}{*}{1.189} & \multirow{2}{*}{0.108} \\
\cline { 1 - 3 } 4 & 38.3 & 12.5 & & & \\
\cline { 1 - 3 } 5 & 35.9 & 11.7 & & & \\
\cline { 1 - 3 } 6 & 30.0 & 9.8 & & & \\
\hline
\end{tabular}

Using the experimental bond stress, the development length of reinforcement $\left(l_{d}\right)$ (minimum length so that steel bars are not pulled out of concrete) in LWAC was calculated according to the eq. (2); and since the value was compared with the provisions of the standards.

$$
u_{m}=\frac{A_{b} f_{y}}{\pi d_{b} l_{d}}=\frac{\pi d_{b}^{2} f_{y}}{4 \pi d_{b} l_{d}}=\frac{d_{b} f_{y}}{4 l_{d}}
$$

With: 
Transport and Communications Science Journal, Vol. 71, Issue 4 (05/2020), 380-387

$\mathrm{f}_{\mathrm{y}}=300 \mathrm{MPa}-$ yield strength of the steel bars

$\mathrm{d}_{\mathrm{b}}=14 \mathrm{~mm}$ (nominal diameter of the steel bars)

$\mathrm{u}_{\mathrm{m}}=\mathrm{f}_{\mathrm{db}}-$ average bond stress determined from the tests (table 3 )

Table 4. The development length calculated from the test results.

\begin{tabular}{|c|c|c|c|c|c|}
\hline No & $\begin{array}{c}\mathrm{u}_{\mathrm{m}} \\
(\mathrm{MPa})\end{array}$ & $\begin{array}{c}\mathrm{l}_{\mathrm{d}} \\
(\mathrm{mm})\end{array}$ & $\begin{array}{c}\mathrm{l}_{\mathrm{d}} \\
(\mathrm{mm})\end{array}$ & $\begin{array}{c}\mathrm{S} \\
(\mathrm{mm})\end{array}$ & $\mathrm{Cv}$ \\
\cline { 1 - 3 } 1 & 12.1 & 86.8 & & & \\
\cline { 1 - 3 } 2 & 11.4 & 101.3 & & & \\
\cline { 1 - 3 } 3 & 9.8 & 106.8 & \multirow{2}{*}{96.11} & \multirow{2}{*}{10.365} & 0.1078 \\
\cline { 1 - 3 } 4 & 12.5 & 84.3 & & & \\
\cline { 1 - 3 } 5 & 11.7 & 89.9 & & & \\
\hline
\end{tabular}

Since the Vietnamese standard has no regulations on the development length of reinforcement in LWAC, the authors compare the experimental results with the foreign standards. According to ACI 318 [11], the development length of reinforcement (diameter smaller than $36 \mathrm{~mm}$ ) in concrete is usually calculated by the formula: $0.04 * A_{b} * f_{y} * \sqrt{f_{c}}$, For lightweight concrete, the development length will be received by multiplying with a coefficient of $1-1.3$. According to Eurocode 2-1992 [12], the bond strength of LWAC and steel reinforcement is lower than that of ordinary concrete $(0.67-1.0$ times, depending on the density of LWAC. The reduction factor is calculated by the formula $\eta 1=0.4+0.6 * \rho_{0} / 2200$ Using CB300-V grade rebar with a nominal diameter of $14 \mathrm{~mm}$ and LWAC used, we have:

$\mathrm{A}_{b}=0.2 \mathrm{in}^{2}-$ area of transversal section of reinforcement

$\mathrm{f}_{\mathrm{y}}=43511 \mathrm{psi}-$ yield strength of reinforcement

$\mathrm{f}^{\prime}{ }_{\mathrm{c}}=5076 \mathrm{psi}-$ nominal compressive strength of LWA

$1_{\mathrm{db}}=4.88$ in $=124 \mathrm{~mm}-$ basic development length of reinforcement in LWAC. This length is $1.3 * l_{\mathrm{db}}$ in minimum with LWAC structure, determined by the formula in the paragraph 4.4 - ACI 318 [11].

Thus according the test results, the development length of rebars in LWAC is from 84 to $108 \mathrm{~mm}$ (about $6 \mathrm{~d}_{\mathrm{b}}$ to $8 \mathrm{~d}_{\mathrm{b}}$ ). This calculated length is smaller than the provisions on the development length of reinforcement in normal concrete as well as in LWAC of American standards (ACI 318-11 [11]). Vietnam Standard TCVN 5574 - 2012 [13] specifies that the minimum anchor length of tensile reinforcement in reinforced concrete structure is $10 \mathrm{~d}_{\mathrm{b}}$. It can be seen that the arrangement of reinforcement in LWAC as required for the development length can follow the rules of the standards of TCVN as well as ACI. However, it is necessary to carry out more experiments in changing the number of samples as well as the material parameters (compressive strength of LWAC, reinforcement style, ...) for purpose of having more accurate and reliable results. 
Transport and Communications Science Journal, Vol. 71, Issue 4 (05/2020), 380-387

\section{CONCLUSIONS}

This paper presented some empirical research to determine the bond behavior between reinforcement and LWAC. Experimental results show that the bond behavior between LWAC and reinforced steel is similar to the one between steel and ordinary concrete. The average bond varied from $9.75 \mathrm{MPa}$ to $12.45 \mathrm{MPa}$, corresponding to the development length of 84 to $108 \mathrm{~mm}$; smaller than the minimum development length specified by ACI $318-124 \mathrm{~mm}$ with the same material. Preliminary experimental results show that the arrangement and the coworking of reinforcement and LWAC in the structures can comply with the current standards. However, more samples and test cases might be carried out to get more accurate and general results.

\section{REFERENCES}

[1] H.J. Chen, C.H. Huang, Z.Y. Kao, Experimental investigation on steel-concrete bond in lightweight and normal weight concrete, Struct. Eng. Mech., 17 (2004) 141-152. https://doi.org/10.12989/sem.2004.17.2.141

[2] W. Yang, J. Yu, Y. Wang, Study on the effect of bond-anchoring factor on bond behavior between deformed bar and shale ceramic concrete. Adv. Mater. Res, 403 (2012) 444-448. https://doi.org/10.4028/www.scientific.net/AMR.403-408.444

[3] D. Zhang, W. Yang, Experimental research on bond behaviors between shale ceramsite lightweight aggregate concrete and bars through pullout tests, J. Mater. Civ. Eng., 27(9) (2015). https://doi.org/10.1061/(ASCE)MT.1943-5533.0001192

[4] B. Mayfield and M. Louati, Properties of pelletized blast furnace slag concrete. Mag. Concr. Res., 42 (150) (1990) 29-36. https://doi.org/10.1680/macr.1990.42.150.29

[5] BS EN 10080:2005, Steel for the reinforcement of concrete, Weldable reinforcing steel. General.

[6] A. Trad, H. Ghanem, R. Ismail, Bond Behaviour of Structural Lightweight Concrete, in: Hordijk D., Luković M. (eds) High Tech Concrete: Where Technology and Engineering Meet. Springer, Cham, 2018. https://doi.org/10.1007/978-3-319-59471-2_71

[7] TCVN1651-2: 2008, Thép cốt bê tông - Phần 2: Thanh thép vằn (Concrete reinforcement - Part 2: Deformed steel bar).

[8] Fritz Leohardt, Vorlesung uber Massivebau, 6 vols, Springer Verlag, Berlin, 1975.

[9] fib.CEB-FIP, Bond of reinforcement in concrete - Bulletin 10, International Federation for Structural Concrete (fib) ed., 2000. https://doi.org/10.35789/fib.BULL.0010

[10] K. Holschemacher, A. Ali, S. Iqbal, Bond of reinforcement in lightweight concrete, in: Insights and Innovations in Structural Engineering, Mechanics and Computation, Cape Town, South Africa, 2016.

[11] ACI 318-11, Building Code Requirements for Structural Concrete and Commentary.

[12] Eurocode 2-1992, Design of concrete structures - part 1-1: general rules and rules for buildings.

[13] TCVN 5574:2012, Kết cấu bê tông và bê tông cốt thép (Concrete and Reinforced Concrete Structure). 